\title{
ARTICLE
}

\section{Bioprospecting and biodiversity investigations of endophytic fungi isolated from Juniperus communis}

\author{
Aruna Vigneshwari', Biljana D. Škrbić², László Kredics', Lubna Abbas¹, László Bakacsy³, \\ Csaba Vágvölgyi ${ }^{1}$, András Szekeres ${ }^{1 *}$
1Department of Microbiology, Faculty of Science and Informatics, University of Szeged, Szeged, Közép fasor 52. H-6726 Szeged, Hungary
${ }^{2}$ University of Novi Sad, Faculty of Technology Novi Sad, Bulevar cara Lazara 1, 21000 Novi Sad, Serbia
${ }^{3}$ Department of Plant Biology, Faculty of Science and Informatics, University of Szeged, Szeged, Közép fasor $52 .$, H-6726 Szeged, Hungary

\begin{abstract}
Endophytes are a group of highly diverse microorganisms that reside within plant tissues without causing obvious symptoms on the host. In our study, Juniperus communis samples were collected from Hungary and used for the isolation of endophytic fungal strains. From 240 plant samples, 76 fungal isolates were recovered and subcultured for homogeneity. The isolates were identified using molecular taxonomical tools at the genus level and their biodiversity parameters were determined. The taxonomic diversity of the isolates was remarkably high, and the most abundant genera were Fusarium, Alternaria and Trichoderma. The secondary metabolites produced by the isolated endophytic fungi were extracted both from their mycelia and their ferment broth and their antimicrobial activities were tested against bacteria, yeasts, and filamentous fungi. In the antimicrobial tests, a total of 58 strains showed antimicrobial activity against at least one test organism. Altogether, $6.67 \%$ of the isolates have antibacterial effects with wide spectrum, and 10 strains showed remarkably high inhibitory percentage against yeast, while the extracts of 11 isolates proved to be active against filamentous fungi.

Acta Biol Szeged 64(2):129-138 (2020)
\end{abstract}

\author{
KEY WORDS \\ biodiversity \\ endophytic fungi \\ Juniperus communis \\ molecular identification

\section{ARTICLE INFORMATION} \\ Submitted \\ 11 November 2020 \\ Accepted \\ 16 December 2020 \\ *Corresponding author \\ E-mail: andras.j.szekeres@gmail.com
}

\section{Introduction}

Throughout evolution, the dependence of human beings on nature has been everlasting. Natural products have among the important sources of medicine for millennia to alleviate and treat various diseases. However, despite the rise of combinatorial chemistry as an integral part of lead discovery process, natural products still play a major role in providing novel and interesting chemical scaffolds for drug discovery with an outstanding development in the areas of separation science (Liu et al. 2019). Although plants are considered as the biofactories of many valuable bioactive compounds, they possess the disadvantage of slow growth rate, while harvesting rare and endangered species also poses a risk (Jia et al. 2016). Therefore, it is necessary to find alternative approaches to produce medicinal plant-derived bioactive metabolites. In recent decades, endophytes have been recognized as sources of several bioactive compounds and are studied as potential sources of novel natural products for medical and commercial exploitation (Selvakumar and Panneerselvam 2018).
The term "endophyte" originally introduced by de Bary (1866) to distinguish fungi - living inside host tissues - from epiphytes, is derived from the Greek word "endon", meaning inside or within and "phyton", meaning plant. The meaning of the word has evolved to include any microorganism that inhabits plants during a period of its life cycle, especially within leaves, branches, and stems, without causing significant damage to its host (Wilson 1995). Endophytes possess a complex relationship with their hosts. They are symbiotic in nature, which may be mutualism, commensalism or saprophytism (Clay and Schardl 2002; Strobel and Daisy 2003). Endophytes can increase the competitive abilities and fitness of plants by increasing their nutrient uptake, resistance to drought and water stress, tolerance to heavy metal stress and high salinity, or their growth rate through biochemical pathways by producing plant growth hormones. For example, researchers proved that most of the endophytic fungi produce indole-3-acetic acid (Tan and Zou 2001; Turbat et al. 2020). It was also suggested that these endophytes initiate the biological degradation of the dead or dying host tissues (Tan and Zou 2001). Although almost all higher plants contain at least one endophytic micro- 
organism, the relationship between microbes and their plant hosts remains one of the least studied biochemical systems, because it is difficult to find the exact physical relationship in the interaction. Given this fact, this longheld association might have created a specific genetic system in endophytes regarding their relationship with plants or vice versa (Strobel 2003).

Endophytic fungi are highly diverse, and more than 1 million species of this fungal group is estimated to be undiscovered (Sun and Guo 2012). They represent an important component of fungal biodiversity and it has also been observed that almost every plant examined to date harbors at least one species of endophytic fungi, while many plants, particularly woody plants, contain hundreds of endophytic species (Petrini 1986; Sahoo et al. 2017). However, various factors affect the distribution of the endophytic fungal community, such as environmental factors (temperature, humidity), and the type and age of the colonized host tissue (Sanchez-Azofeifa et al. 2012). Most of the studies reported that Dothideomycetes and Sordariomycetes are the dominant classes found in medicinal plants, but the diversity of the endophytic fungi also differs according to the geographical regions (Kharwar et al. 2008; Dhayanithy et al. 2019).

Endophytic fungi of medicinal plants are potential sources of novel bioactive compounds and some have also been proved to produce plant-associated therapeutic metabolites (Huang et al. 2007; Vigneshwari et al. 2019). The endophytic fungi such as Acremonium, Alternaria, Aspergillus, Cephalosporium, Chaetomium, Chloridium, Choanephora, Colletotrichum, Fusarium, Gliocladium, Hypoxylon, Paecilomyces, Penicillium, Pestalotiopsis, Talaromyces, and Trichoderma from different medicinal plants have been reported as sources of several bioactive compounds (Rana et al. 2019). A diverse array of endophytic metabolites exhibited antimicrobial activity against various pathogenic microbiota, and these can be used in pharmaceuticals, medicine, and agriculture (Gunatilaka et al. 2006; Yo et al. 2017; Sim et al. 2020).

The common juniper (Juniperus communis L.) is a bush or small evergreen tree which has been commonly referred to as herbal medicine in ancient times. It contains various chemical constituents including flavonoids, volatile oils, coumarins and therapeutically important anticancer lignans, podophyllotoxin and deoxypodophyllotoxin (Hartwell et al. 1953). Previous studies reported the isolation and characterization of endophytic fungi harboured in Juniperus plants sampled from the natural populations in Dortmund and Haltern (Germany), and Jammu and Kashmir (India). This resulted in the discovery of a deoxypodophyllotoxin-producing endophytic fungus harboured in J. communis (Kusari et al. 2009). The endophytic fungi isolated from Juniperus trees such as Penicillium and Aspergillus were also found to exhibit antimicrobial activities (Gherbawy and Elhariry 2016).

In our study, isolation and identification of endophytic fungi from $J$. communis were undertaken and their biodiversity parameters evaluated. Furthermore, the antimicrobial activities of metabolites extracted with different organic solvents from both the ferment broth and mycelia of isolated endophytic fungi were also determined.

\section{Materials and Methods}

\section{Collection of J. communis samples}

Fresh, healthy parts of the J. communis plants were collected during the late autumn of 2015, 2016 and 2017 (Table 1.). GPS coordinates of the sampling sites were recorded. All plant specimens have been identified and authenticated by experts. Collected specimens were placed into sealed plastic bags, labelled with the number and date of collection and stored at $4{ }^{\circ} \mathrm{C}$ until processing.

\section{Isolation of endophytes}

Isolation of endophytic fungi from plant parts was performed according to the method described by Garyali (2013) with minor modifications. The plant materials were rinsed in running tap water to remove dust and debris, and the specimens were cut into small segments of about 0.5 to $1 \mathrm{~cm}$ in length using a sterile blade. The leaf, twig, root, and cone parts were separated, and these parts were examined for their fungal endophyte content.

The plant segments were surface sterilized to kill the epiphytic microorganisms by sequentially immersing the plant material in $70 \%$ ethanol for $60 \mathrm{sec}$, washing with sterile distilled water and then steeping in $0.01 \%$ mercuric chloride (VWR International, Hungary) for $30 \mathrm{sec}$. Finally, the specimens were washed again with sterile distilled water 2-3 times and then allowed to dry on a sterile blotting paper. Each segment was placed onto the surface of PDA medium (VWR International, Hungary) supplemented with ampicillin $(50 \mu \mathrm{g} / \mathrm{mL}$, Merck, Hungary) in Petri dishes. They were incubated at $25^{\circ} \mathrm{C}$ for 5-10 days and checked daily for the growth of fungal colonies. Pure isolates were obtained by picking individual colonies from the plates and transferring them onto fresh PDA medium where they were incubated at $25^{\circ} \mathrm{C}$ for 10 days. Each fungal culture was checked again for purity, transferred separately to PDA slants, maintained at $4{ }^{\circ} \mathrm{C}$ and deposited in the Szeged Microbiological Collection (SZMC, Hungary; http://www.wfcc.info/ccinfo/collection/by_id/987).

\section{Molecular identification of isolates}

Genomic DNA was isolated from fungal mycelia grown in PDB medium (VWR International, Hungary) at $25^{\circ} \mathrm{C}$ 
for 7 days. Isolation and purification of genomic DNA was performed using the EZNA Fungal DNA Mini Kit (Omega Bio-tek, Norcross, USA) according to the manufacturer's instructions.

DNA fragments containing the ITS region of the ribosomal DNA gene cluster were amplified using the primers ITS1 and ITS4 (White et al. 1990). Polymerase chain reaction (PCR) was performed in a total volume of $25 \mu \mathrm{L}$ consisting of $2.5 \mu \mathrm{L}$ of PCR reaction buffer (10 $\times$ Standard Reaction Buffer), $2 \mu \mathrm{L}$ of $2 \mathrm{mM}$ dNTP, $0.5 \mu \mathrm{L}$ of $10 \mu \mathrm{M}$ ITS1 forward primer (5'-TCCGTAGGTGAACCTGCGG-3'), $0.5 \mu \mathrm{L}$ of $10 \mu \mathrm{M}$ ITS 4 reverse primer (5'-TCCTCCGCTTATTGATATGC-3'), $2 \mu \mathrm{L}$ of DNA template and $0.125 \mu \mathrm{L}$ of $P f u$ DNA-polymerase (Fermentas). The PCR amplification profile consisted of an initial denaturation at $94^{\circ} \mathrm{C}$ for $5 \mathrm{~min}$, followed by 35 amplification cycles $\left(30 \mathrm{sec}\right.$ at $94^{\circ} \mathrm{C}, 40 \mathrm{sec}$ at $48^{\circ} \mathrm{C}$, and 1 $\min 72^{\circ} \mathrm{C}$ ) and a final extension at $72^{\circ} \mathrm{C}$ for $3 \mathrm{~min}$. PCR products were separated using horizontal gel electrophoresis in 1\% agarose gel supplemented with ethidium bromide at $0.1 \mu \mathrm{g} / \mathrm{mL}$ final concentration. Electrophoresis was performed for $30 \mathrm{~min}$ at $100 \mathrm{~V}$. Separated DNA fragments were visualized using a UV transilluminator (UVP-BioDoc-It ${ }^{\mathrm{TM}}$ imaging Systems, Analytik Jena, Jena, Germany). 1000 bp marker (Fermentas) was used to determine the size of the products.

Amplified DNA fragments were sequenced (BaseClear, The Netherlands) and used for BLAST similarity search at the website of the National Center for Biotechnology Information (http://www.ncbi.nlm.nih.gov/BLAST). Genus level identification was carried out from the lowest expect value of the BLAST output.

\section{Screening of bioactive metabolite-producing endophytic fungi}

\section{Secondary metabolite extraction}

The isolated endophytic fungi were cultured for 7 days at $25^{\circ} \mathrm{C}$ in $50 \mathrm{~mL}$ PDB medium. Then the mycelia were separated from the broth by filtration through a cheese cloth and dried overnight in an oven until constant weight. Then $25 \mathrm{~mL}$ distilled water was added to the dry material, which was then sonicated for $20 \mathrm{~min}$ after the addition of an aliquot of liquid nitrogen to maintain the chilled condition. After that the extraction of the aqueous samples was done with a $25 \mathrm{~mL}$ mixture of chloroform and methanol $(4: 1, \mathrm{~V} / \mathrm{V})$ and extraction was repeated 3 times. The ferment broths were extracted 3 times sequentially with 50-50 $\mathrm{mL}$ of hexane, ethyl acetate and chloroform, respectively, and both extract series were pooled. The organic solvents were removed by a rotary evaporator (IKA HB10 basic, VWR International, Hungary) in vacuum at $30^{\circ} \mathrm{C}$ from each pooled extract including ethyl acetate, chloroform, as well as chloroform and methanol $(4: 1, \mathrm{~V} / \mathrm{V})$ fractions. The resulted 4 dry samples per each isolate were stored at $-20^{\circ} \mathrm{C}$ and resuspended in $1 \mathrm{~mL}$ of HPLC grade methanol (VWR International, Hungary) prior to use.

\section{Activity assays against bacteria and yeast}

For testing the antibacterial potential of the crude extracts, $400 \mu \mathrm{L}$ of the methanolic extracts were transferred into new Eppendorf tubes and dissolved in $1 \mathrm{~mL} \mathrm{10 \%}$ methanol after evaporation. These extracts were tested against two Gram-negative (Escherichia coli SZMC 6271 and Pseudomonas aeruoginosa SZMC 23290), two Gram-positive bacteria (Staphylococcus aureus SZMC 14611 and Bacillus subtilis SZMC 0209) and two yeasts (Candida albicans SZMC 1533 and C. krusei SZMC 1352). For the assay, the suspensions of the microbes were prepared from overnight cultures, which were cultivated in Luria-Bertani broth (10 g tryptone, 5 g yeast extract and $5 \mathrm{~g} \mathrm{NaCl}$ in $1 \mathrm{~L}$ distilled water) and yeast extract peptone dextrose broth (20 g peptone, $10 \mathrm{~g}$ yeast extract and $20 \mathrm{~g}$ glucose in $1 \mathrm{~L}$ distilled water) for the bacteria and yeasts, respectively, at $37^{\circ} \mathrm{C}$. Their concentrations were set to $4 \times 10^{5}$ cells $/ \mathrm{mL}$ with sterile media. Then, 96 -well plates were prepared by dispensing $100 \mu \mathrm{L}$ suspension containing the bacterial or yeast cells, $100 \mu \mathrm{L}$ of the extract dissolved in $10 \%$ of methanol was added into the wells, which were then incubated for $24 \mathrm{~h}$ at $37^{\circ} \mathrm{C}$. The mixture of $100 \mu \mathrm{L}$ broth and $100 \mu \mathrm{L} \mathrm{10 \%} \mathrm{methanol} \mathrm{was} \mathrm{used} \mathrm{as}$ the blank sample for background correction, while 100 $\mu \mathrm{L}$ of the microbial suspension supplemented with 100 $\mu \mathrm{L} 10 \%$ methanol was applied as the negative control. The positive control contained ampicillin $(100 \mu \mathrm{g} / \mathrm{mL}$, Merck, Hungary) for bacteria and nystatin $(10 \mu \mathrm{g} / \mathrm{mL}$, Merck, Hungary) for fungi. The inhibitory effects of each derivative were spectrophotometrically (SPECTROstar Nano, BMG Labtech, Ordenberg, Germany) determined at $620 \mathrm{~nm}$ after incubation, and the inhibition rate was calculated as the percentage of the positive control after blank correction.

\section{Activity assay against filamentous fungi}

To determine the potential antifungal activity of the fungal extracts against filamentous fungi, agar well diffusion assay was carried out. Evaporated samples of crude extracts $(400 \mu \mathrm{L})$ were dissolved in $1 \mathrm{~mL} 10 \%$ methanol. Four holes with a diameter of $8 \mathrm{~mm}$ were bored into PDA plates, at the $2.5 \mathrm{~cm}$ distances around the centre of the plate. Then precultured $\left(25^{\circ} \mathrm{C}, 7\right.$ days $)$ Fusarium culmorum SZMC 11039 and Rhizoctonia solani SZMC 21048 strains were placed in the centre of plates with agar plugs. After that, $100 \mu \mathrm{L}$ of samples was applied into each hole. As solvent control, 10\% methanol was used. Mycelial plug inoculated without any extracts was used as a control. 
A

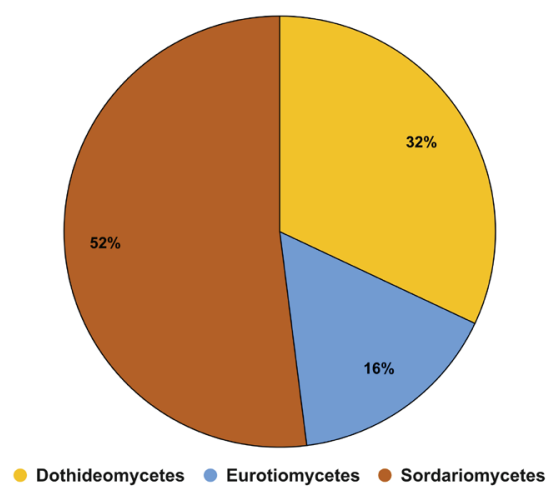

B

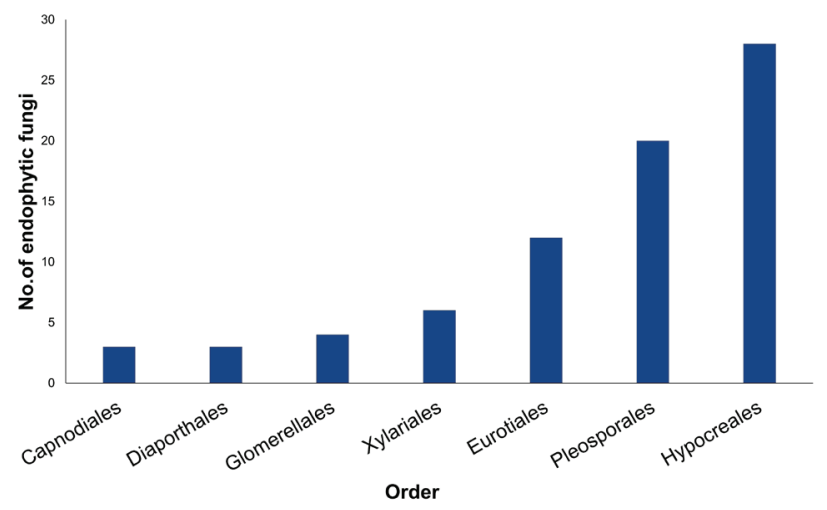

Figure 1. Distribution of endophytic fungi isolated from J. communis into classes (A) and orders (B).

Antifungal activity of the samples was determined by the size of the inhibition zone.

\section{Biodiversity mapping of endophytic fungi of J. communis}

\section{Calculating isolation rate and diversity index}

The isolation rate of endophytic fungi was calculated as the total number of tissue segments infected by fungi divided by the total number of tissue segments incubated (Kumar and Hyde, 2004).

The diversity of endophytic fungi isolated from 3 plants were evaluated using the, Shannon-Weiner Index $\left(\mathrm{H}^{\prime}\right)$, Simpson's diversity index (1-D), evenness Index $(\mathrm{J})$ and Margalef richness index ( $D$ mg) (Hoffman et al. 2008; Suryanarayanand and Kumaresan 2000; Kusari et al. 2012). All the diversity indices were calculated plantwise and also tissuewise to analyse the host and tissue specificity of endophytic fungi.

\section{Statistical analysis}

Statistical analyses for biodiversity calculations were carried out in R 3.5.2 ( $\mathrm{R}$ core Team 2019). The diversity

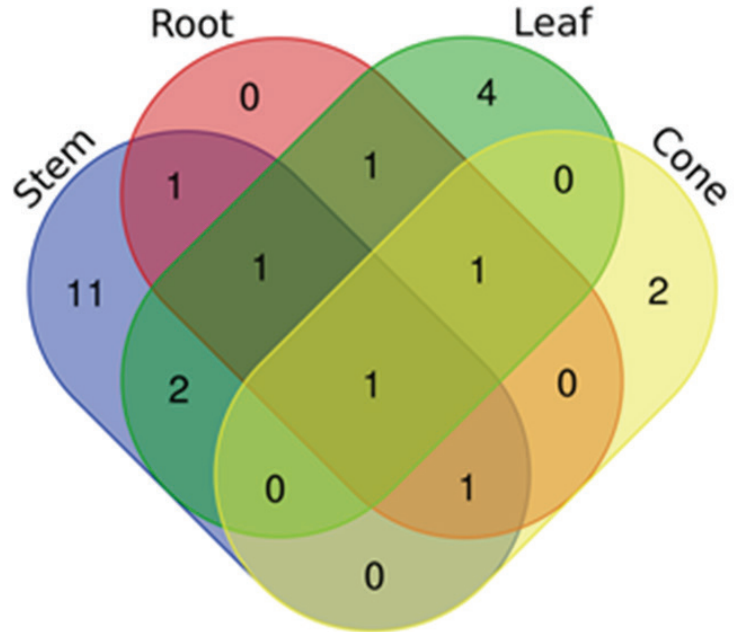

Figure 2. Venn diagram showing the common and unique fungi along the tissues of $J$. communis.

indices were calculated using the Vegan package from $\mathrm{R}$ 3.5.2 (Oksanen et al. 2018). One-way analysis of variance (ANOVA) was carried out to test the effect of plant species or tissue type (stem and root) on the isolation rate and genus richness of endophytic fungi. Post hoc Tukey's Honest Significant Difference tests were performed to observe the significant differences among the plant species or tissue types at $\mathrm{P}<0.05$ level.

\section{Results}

\section{Investigation of endophytic fungi isolated from J. com- munis}

The J. communis plant parts were collected from Southern Hungarian areas and their endophytes were isolated and purified, which was followed by sequence-based molecular identification (Table 1).

Altogether, 240 parts were tested involving 60 cuttings of leaf, stem, root and cone from 12 different plant samples of J. communis. A total of 75 endophytic fungi distributed into 3 main classes and 7 main orders were isolated from J. communis (Fig. 1). The isolation rates were 0.51, 0.3, 0.35 and 0.18 for stem, leaf, root and cone, respectively. The predominant class was found to be Sordariomycetes, similarly to previous studies on Juniperus endophytes (Kusari et al. 2009). Most of the isolates belonged to Hypocreales, while the rest of them were members of the taxa Pleosporales and Eurotiales (Table 1).

To characterize the biodiversity of J. communis EF, the Shannon diversity index $\left(H^{\prime}\right)$ Simpson's diversity index $(1-D)$, and Margalef's richness ( $D m g$ ) have been calculated. The Shannon-index revealed higher certainty of endo- 
Table 1. Endophytic fungi isolated in this study.

\begin{tabular}{|c|c|c|c|c|}
\hline Collection code & GPS coordinates & Plant part & Species & Genbank ID of ITS \\
\hline SZMC 27149 & N 4653.338' / E 019²4.483' & Stem & Alternaria sp. & MT940776 \\
\hline SZMC 27150 & N 4653.340' / E 019²4.528' & Stem & Alternaria sp. & MT940777 \\
\hline SZMC 27151 & N 4653.340' / E 019²4.528' & Stem & Alternaria sp. & MT940778 \\
\hline SZMC 27152 & N 4653.338' E 019²4.483' & Stem & Alternaria sp. & MT940779 \\
\hline SZMC 27153 & N 4653.345' E 019²4.501' & Stem & Alternaria sp. & MT940780 \\
\hline SZMC 27154 & N 4653.345' E 019²4.501' & Stem & Alternaria sp. & MT940781 \\
\hline SZMC 27155 & N 4653.345' E 019²4.501' & Leaf & Alternaria sp. & MT940782 \\
\hline SZMC 27156 & N 4653.345' E 019²4.501' & Stem & Alternaria sp. & MT940783 \\
\hline SZMC 27157 & N 465․345' E 019²4.501' & Stem & Alternaria sp. & MT940784 \\
\hline SZMC 27158 & N 4653.338' E 019²4.483' & Leaf & Alternaria sp. & MT940785 \\
\hline SZMC 27159 & N 4653.345' E 019²4.501' & Stem & Alternaria sp. & MT940786 \\
\hline SZMC 27160 & N 4653.345' E 019²4.501' & Stem & Alternaria sp. & MT940787 \\
\hline SZMC 27161 & N 4653.345' E 019²4.501' & Stem & Alternaria sp. & MT940788 \\
\hline SZMC 27162 & N 4653.345' E 019²4.501' & Stem & Alternaria sp. & MT940789 \\
\hline SZMC 27163 & N 4653.338' E 019²4.483' & Stem & Alternaria sp. & MT940790 \\
\hline SZMC 27164 & N 4653.345' E 019²4.501' & Stem & Aspergillus sp. & MT993364 \\
\hline SZMC 27165 & N 4653.345' E 019²4.501' & Stem & Aspergillus sp. & MT993365 \\
\hline SZMC 27166 & N 4653.338' E 019²4.483' & Stem & Aspergillus sp. & MT993366 \\
\hline SZMC 27167 & N 4653.345' E 019²4.501' & Stem & Aspergillus sp. & MT993367 \\
\hline SZMC 27168 & N 4653.345' E 019²4.501' & Stem & Aspergillus sp. & MT993368 \\
\hline SZMC 27169 & N 4653.330' E 019²4.478' & Stem & Cladosporium sp. & MT993369 \\
\hline SZMC 27170 & N 4653.330' E 019²4.478' & Stem & Cladosporium sp. & MT993370 \\
\hline SZMC 27171 & N 4653.330' E 019²4.478' & Stem & Cladosporium sp. & MT993371 \\
\hline SZMC 27172 & N 4653.338' E 019²4.483' & Stem & Cladosporium sp. & MT993372 \\
\hline SZMC 27173 & N 4653.330' E 019²4.478' & Root & Cladosporium sp. & MT994503 \\
\hline SZMC 27174 & N 4653.330' E 019²4.478' & Stem & Colletotrichum sp. & MT994504 \\
\hline SZMC 27175 & N 4653.330' E 019²4.478' & Leaf & Colletotrichum sp. & MT994505 \\
\hline SZMC 27176 & N 4653.330' E 019²4.478' & Stem & Colletotrichum sp. & MT994506 \\
\hline SZMC 27177 & N 4653.342' E 019²4.474' & Stem & Curvularia sp. & MT994507 \\
\hline SZMC 27178 & N 4653.330' E 019²4.478' & Stem & Curvularia sp. & MT994508 \\
\hline SZMC 27179 & N 4653.330' E 019²4.478' & Stem & Didymella sp. & MT994509 \\
\hline SZMC 27180 & N 4653.338' E $019^{\circ} 24.483^{\prime}$ & Stem & Fusarium sp. & MT994510 \\
\hline SZMC 27181 & N 4653.342' E 019²4.474' & Stem & Fusarium sp. & MT994511 \\
\hline SZMC 27182 & N 4653.340' E 019²4.528' & Stem & Fusarium sp. & MT994512 \\
\hline SZMC 27183 & N 4653.338' E 019²4.483' & Leaf & Fusarium sp. & MT994513 \\
\hline SZMC 27184 & N 465․342' E 019²4.474' & Root & Fusarium sp. & MT982177 \\
\hline SZMC 27185 & N 4653.340' E 019²4.528' & Root & Fusarium sp. & MT982178 \\
\hline SZMC 27186 & N 4653.338' E 019²4.483' & Root & Fusarium sp. & MT982179 \\
\hline SZMC 27187 & N 4653.340' E 019²4.528' & Root & Fusarium sp. & MT982180 \\
\hline SZMC 27188 & N 4653.340' E 019²4.528' & Root & Fusarium sp. & MT982181 \\
\hline SZMC 27189 & N 4653.340' E 019²4.528' & Root & Fusarium sp. & MT982182 \\
\hline SZMC 27190 & N 4653.338' E 019²4.483' & Root & Fusarium sp. & MT982183 \\
\hline SZMC 27191 & N 4653.340' E 019²4.528' & Root & Fusarium sp. & MT982184 \\
\hline SZMC 27192 & N 4653.340' E 019²4.528' & Root & Fusarium sp. & MT982185 \\
\hline SZMC 27193 & N 4653.340' E 019²4.528' & Root & Fusarium sp. & MT982186 \\
\hline SZMC 27194 & N 4653.342' E 019²4.474' & Root & Fusarium sp. & MT982187 \\
\hline SZMC 27195 & N 4653.340' E 019²4.528' & Root & Fusarium sp. & MT982188 \\
\hline SZMC 27196 & N 4653.340' E 019²4.528' & Root & Fusarium sp. & MT982189 \\
\hline SZMC 27197 & N 4653.338' E 019²4.483' & Root & Penicillum sp. & MT982190 \\
\hline SZMC 27198 & N 4653.340' E 019²4.528' & Leaf & Penicillum sp. & MT982191 \\
\hline
\end{tabular}


Vigneshwari et al.

Table 1. Continued.

\begin{tabular}{|c|c|c|c|c|}
\hline Collection code & GPS coordinates & Plant part & Species & Genbank ID of ITS \\
\hline SZMC 27199 & N 465․ $342^{\prime}$ E $019^{\circ} 24.474^{\prime}$ & Leaf & Penicillium sp. & MT982192 \\
\hline SZMC 27200 & N 465․340' E $019^{\circ} 24.528^{\prime}$ & Leaf & Penicillium sp. & Мт982193 \\
\hline SZMC 27201 & N 465․338' E $019^{\circ} 24.483^{\prime}$ & Leaf & Penicillium sp. & МT982194 \\
\hline SZMC 27202 & N 465․ $5342^{\prime}$ E $019^{\circ} 24.474^{\prime}$ & Leaf & Penicillum sp. & MT982195 \\
\hline SZMC 27203 & N 465․ $53.340^{\prime}$ E $019^{\circ} 24.528^{\prime}$ & Leaf & Penicillum sp. & MT982196 \\
\hline SZMC 27204 & N 465․ $340^{\prime}$ E $019^{\circ} 24.528^{\prime}$ & Leaf & Pestalotiopsis sp. & МT982197 \\
\hline SZMC 27205 & N 465ㄱ.340' E $019^{\circ} 24.528^{\prime}$ & Leaf & Pestalotiopsis sp. & МT982198 \\
\hline SZMC 27206 & N 465․ $53.338^{\prime}$ E $019^{\circ} 24.483^{\prime}$ & Leaf & Pestalotiopsis sp. & MT982199 \\
\hline SZMC 27207 & N 465․ $53.340^{\prime}$ E $019^{\circ} 24.528^{\prime}$ & Leaf & Bipolaris sp. & MT982200 \\
\hline SZMC 27208 & N 465․ $53.340^{\prime}$ E $019^{\circ} 24.528^{\prime}$ & Leaf & Bipolaris sp. & MT982201 \\
\hline SZMC 27209 & N 465․ $53.38^{\prime}$ E $019^{\circ} 24.483^{\prime}$ & Leaf & Phomopsis sp. & MT982202 \\
\hline SZMC 27210 & N 465ㄱ.340' E $019^{\circ} 24.528^{\prime}$ & Leaf & Trichoderma sp. & МT997192 \\
\hline SZMC 27211 & N 465․ $542^{\prime}$ E $019^{\circ} 24.474^{\prime}$ & Leaf & Trichoderma sp. & МT997193 \\
\hline SZMC 27212 & N 465․ $342^{\prime}$ E $019^{\circ} 24.474^{\prime}$ & Cone & Trichoderma sp. & МT997194 \\
\hline SZMC 27213 & N 465․ $53.342^{\prime}$ E $019^{\circ} 24.474^{\prime}$ & Cone & Trichoderma sp. & MT997195 \\
\hline SZMC 27214 & N 465․ $542^{\prime}$ E $019^{\circ} 24.474^{\prime}$ & Cone & Trichoderma sp. & MT997196 \\
\hline SZMC 27215 & N 465․ $342^{\prime}$ E $019^{\circ} 24.474^{\prime}$ & Cone & Trichoderma sp. & MT997197 \\
\hline SZMC 27216 & N 465․ $53.338^{\prime}$ E $019^{\circ} 24.483^{\prime}$ & Cone & Trichoderma sp. & MT997198 \\
\hline SZMC 27217 & N 465․ $342^{\prime}$ E $019^{\circ} 24.474^{\prime}$ & Cone & Trichoderma sp. & МT997199 \\
\hline SZMC 27218 & N 465․342' E $019^{\circ} 24.474^{\prime}$ & Cone & Trichoderma sp. & MT997200 \\
\hline SZMC 27219 & N 465․ $5340^{\prime}$ E $019^{\circ} 24.528^{\prime}$ & Cone & Trichoderma sp. & MT997201 \\
\hline SZMC 27220 & N 465․ $340^{\prime}$ E $019^{\circ} 24.528^{\prime}$ & Cone & Xylaria sp. & MT997202 \\
\hline SZMC 27221 & N 465․338' E $019^{\circ} 24.483^{\prime}$ & Cone & Xylaria sp. & MT997203 \\
\hline SZMC 27222 & N 465․338' E $019^{\circ} 24.483^{\prime}$ & Cone & Xylaria sp. & МT997204 \\
\hline SZMC 27031 & N 465․ $53.38^{\prime}$ E $019^{\circ} 24.483^{\prime}$ & Stem & Purpureocillium sp. & MT997205 \\
\hline
\end{tabular}

phytic fungal genus consistency in the stem compared to that of the other parts of J. communis. Moreover, the Simpson's-index clearly showed that the stem harboured highly diverse fungal endophytes compared to those harboured by other plant parts. Finally, based on Margalef'sindex the stems had high taxonomic richness, while the cone had the lowest compared to the other tissues of $J$. communis (Table 2.).

The stems of J. communis harboured 11 unique fungi, whereas 4 and 2 were found in leaf and cone samples (Fig. 2). Interestingly, the roots of J. communis did not harbour any unique fungi. This shows that some genus seems to be tissue specific. Xylaria sp. were found only in the cone, while Pestalotiopsis and Bipolaris were found only in the leaf and stem respectively, whereas Curvularia, Aspergillus, Didymella and Purpureocillium sp. were specifically found in stems (Fig. 3). Fusarium strains were more abundant in roots than in other tissues.

\section{Antimicrobial effects of fungal extracts of $\mathrm{J}$. communis endophytes}

Gram-positive bacteria were found to be more susceptible to the extracted endophytic metabolites than Gram-negative ones due to the higher number of highly active (>90\%) extracts (Fig. 4). For B. subtilis, the highest number of highly active extracts was recorded in the case of the

Table 2. Biodiversity parameters of endophytic fungi isolated from J. communis.

\begin{tabular}{|c|c|c|c|c|c|}
\hline Diversity index & Stem & Root & Leaf & Cone & Total \\
\hline Simpson's Dominance (D) & 0.912 & 0.775 & 0.788 & 0.666 & 0.92 \\
\hline Shannon $\left(\mathrm{H}^{\prime}\right)$ & 2.582 & 1.630 & 1.950 & 1.214 & 2.85 \\
\hline Pielou's evenness (J) & 0.931 & 0.910 & 0.847 & 0.48 & 0.89 \\
\hline Margeref richness & 4.218 & 1.894 & 3.176 & 1.365 & 5.32 \\
\hline
\end{tabular}


Table 3. List of the endophytic fungi extracts showing inhibitory activities to plant pathogenic fungi (HEX - hexane; CLF - chloroform; C:M - chloroform: methanol (4:1) extract of mycelia; EtOAc - Ethyl acetate).

\begin{tabular}{|c|c|c|c|c|c|c|c|c|}
\hline \multirow{2}{*}{ Collection code } & \multicolumn{4}{|c|}{ F. culmorum } & \multicolumn{4}{|c|}{ R. solani } \\
\hline & HEX & CLF & EtOAc & $C: M$ & HEX & CLF & EtOAc & C:M \\
\hline SZMC 27198 & - & - & - & - & - & - & - & + \\
\hline SZMC 27206 & - & - & - & + & - & - & ++ & - \\
\hline SZMC 27209 & - & - & - & + & - & - & - & - \\
\hline SZMC 27210 & - & - & - & - & - & - & - & + \\
\hline SZMC 27211 & - & - & - & - & - & - & - & + \\
\hline SZMC 27212 & - & - & - & + & - & - & - & +++ \\
\hline SZMC 27213 & - & - & - & - & - & - & - & + \\
\hline SZMC 27214 & - & - & - & - & - & - & + & - \\
\hline SZMC 27215 & - & - & - & - & - & - & + & ++ \\
\hline SZMC 27216 & - & - & - & - & - & - & - & + \\
\hline SZMC 27218 & - & - & - & - & - & - & - & +++ \\
\hline
\end{tabular}

ethyl acetate extracts of ferment broth (55), while the lowest amount of effective extracts (19) was obtained from the hexane-based solvent partitions. The mycelial extracts proved to be the most effective against $E$. coli and $P$. aeruginosa, as the numbers of the active extracts were 25 and 27, respectively. In the case of $S$. aureus, the highest number of effective extracts was obtained for the ethyl acetate extracts (43), followed by chloroform-partitioned ferment broth samples (37). It is important to highlight that strain SZMC 27155 was highly active against all bacteria, but it was not active against the tested yeasts and plant pathogenic fungi. The ethyl acetate and chloroform extracts of strains SZMC 27164 and SZMC 27031 showed remarkable inhibitory effects to all tested bacteria and the mycelial extracts of these isolates were also active against plant pathogenic fungi and yeasts. The Trichoderma isolates of this plant showed activity at least against one

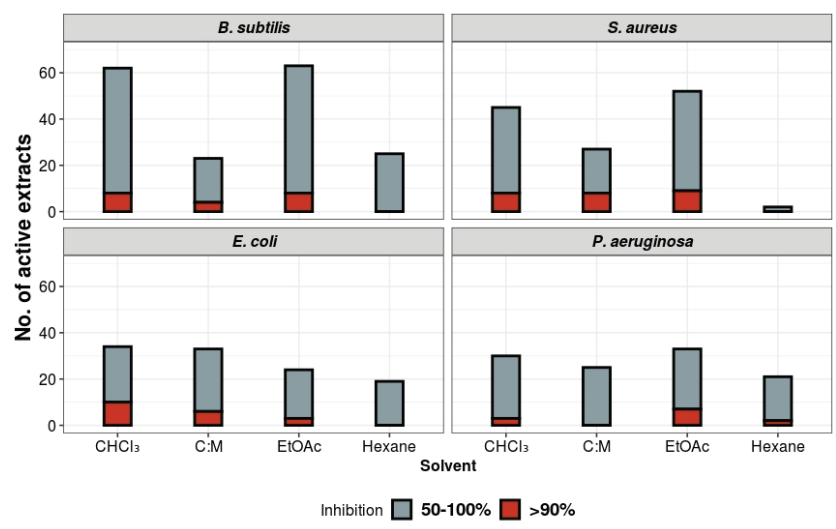

Figure 4. Summary of the antibacterial effects of endophytic extracts isolated from J. communis (C:M - chloroform:methanol (4:1, V/V) extract of mycelia). test microbe. The extracts of strain SZMC 27205 showed significant inhibitory activity to both Gram-positive and

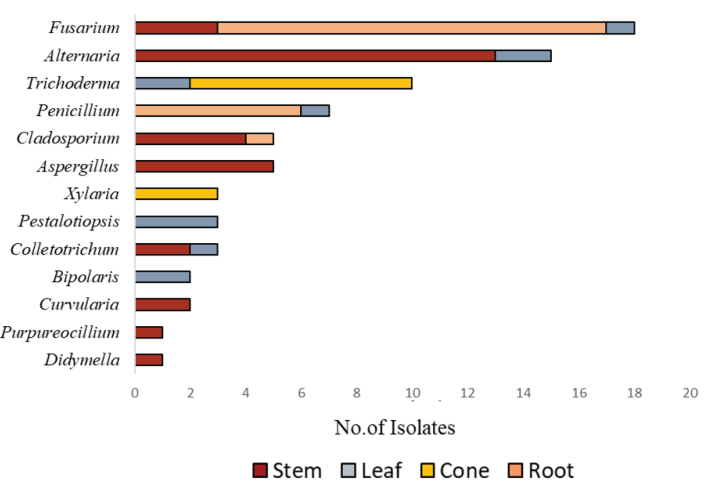

Figure 3. Distribution of endophytic fungi of $J$. communis at the genus level.

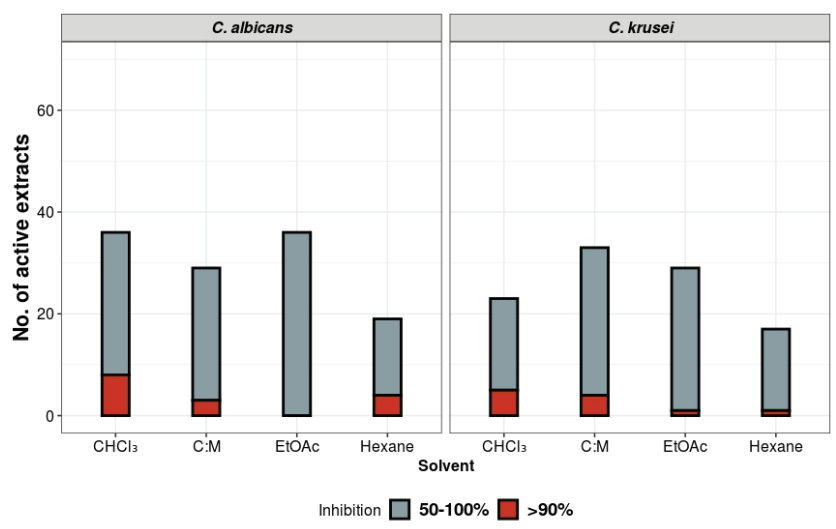

Fig. 5. Summary of the antifungal effects of endophytic extracts isolated from J. communis (C:M - chloroform:methanol (4:1, V/V) extract of mycelia). 
Gram-negative bacteria. With respect to taxa, Fusarium, Pestalotiopsis, Trichoderma, Aspergillus and Purpureocillium strains showed high bioactivities and will be suitable for further investigations.

Altogether, 27 extracts showed inhibitory effects to yeasts, which is over $90 \%$ (Fig. 5). Interestingly, both the chloroform extract of the ferment broth and the mycelial extracts inhibited C. albicans, while C. krusei was mainly susceptible to the ethyl acetate extract of the ferment broth and to the mycelial extracts.

Previous works showed that the endophytic fungi of $J$. communis were excellent sources of antimicrobial compounds (Gherbawy and Elhariry 2016). In our study at least one solvent partition of 58 isolates was active against $B$. subtilis, $S$. aureus and C. albicans. However, only a few extracts, particularly the mycelial extracts were found to be active against the tested filamentous fungi (Table 3). Specifically, mycelial extracts of Trichoderma and Purpureocillium strains were active against both of the tested fungi. F. culmorum was found to be more resistant than R. solani.

\section{Discussion}

Endophytic fungi are highly diverse, and their investigation is very important from different plants to understand the biodiversity and structure of the endophytic fungal community, which mostly depends on the plant physiology, biogeographical factors and their interplay with other pathogenic microorganisms associated with their host plant (Arnold et al. 2007). Only a few studies have been carried out to study the endophytic fungal communities in Hungary (Knapp et al. 2012). Therefore, in the present work, 75 endophytic strains were isolated from J. communis from the Southern part of Hungary and the antimicrobial activities of their metabolites evaluated.

In our study, the culture-dependent method was followed for the molecular identification of fungal isolates. Based on ITS sequence analysis, the isolates were characterized into 7 orders of 3 classes. All the isolated fungi belonged to Ascomycota, which includes the classes Dothideomycetes, Sordariomycetes and Eurotiomycetes. Sordariomycetes was the dominant class (52\%) followed by Dothideomycetes (32\%) and Eurotiomycetes (16\%). Such dominance of Sordariomycetes as endophytes has also been reported from several plants, e.g., Phragmites (Sim et al. 2018) and lichens (U'Ren et al. 2016) indicating that Sordariomycetes are ubiquitous among the plant kingdom. Totally, 14 genera (Alternaria, Aspergillus, Bipolaris, Cladosporium, Colletotrichum, Curvularia, Didymella, Fusarium, Penicillium, Pestalotiopsis, Phomopsis, Purpureocillium, Trichoderma and Xylaria) were identified (Table 1), where the relative abundances of Fusarium, Alternaria and Trichoderma were the highest (Fig. 3). The isolation rates of endophytic fungi were found to be the highest from stem followed by leaf, similarly to the results of previous studies on J. communis endophytes (Gherbawy and Elhariry 2016), whereas similar studies in other plants showed higher isolation rate values from the leaf compared to stems (Alurappa and Chowdappa 2018).

One of the most important properties of endophytic fungi is that they produce a wide variety of compounds that protect the plants from plant pathogens (Tan and Zou 2001; Strobel and Daisy 2003). In our cases, a total of 58 isolates (77\%) showed antibacterial activity against at least one test microrganism. Altogether, $16 \%$ of the isolates had antibacterial effects with wide spectrum. Five strains showed remarkably high inhibitory values (>90\%) to all the tested strains. Furthermore, regarding the antifungal activity, 43 and 31extracts were active against $C$. albicans, and C. krusei, respectively, while 3 and 11 showed inhibitory effects against $F$. culmorum and $R$. solani.

Future examinations could reveal the chemical nature of the active metabolites and their potential for practical (e.g., pharmaceutical, argricultural) applications.

\section{Acknowledgments}

This work was supported by the Hungarian Government and the European Union within the frames of the Széchenyi 2020 Programme (grant GINOP-2.3.2-15-2016-00012). The relating research group was also supported by the grant OTKA K-128659 from the National Research, Development and Innovation Office providing infrastructure and research equipment. B.D.S. and C.V. also acknowledge the contribution of the TÉT_16-1-2016-0148 (National Research, Development and Innovation Fund of Hungary) and HUSRB/1602/41/0031 (PLANTSVITA; Hungary-Serbia IPA CBC Programme) projects.

\section{References}

Alurappa R, Chowdappa S (2018) Antimicrobial activity and phytochemical analysis of endophytic fungal extracts isolated from ethno-pharmaceutical plant Rauwolfia tetraphylla L. J Pure Appl Microbiol 12:317-332.

Arnold AE, Engelbrecht MJB (2007) Fungal endophytes nearly double minimum leaf conductance in seedlings of a neotropical tree species. J Tropical Ecology 23(3):369372.

Clay K, Schardl C (2002) Evolutionary origins and ecological consequences of endophyte symbiosis with grasses. Am Nat 160:S99-127. 
de Bary, A (1866) Morphologie und Physiologie der Pilze, Flechten und Myxomyceten. W. Engelmann, Leipzig.

Dhayanithy G, Subban K, Chelliah J (2019) Diversity and biological activities of endophytic fungi associated with Catharanthus roseus. BMC Microbiol 19:22.

Garyali S, Kumar A, Reddy MS (2013) Taxol production by an endophytic fungus, Fusarium redolens, isolated from Himalayan yew. J Microbiol Biotechnol 23:1372-1380.

Gherbawy YA, Elhariry HM (2016) Endophytic fungi associated with high-altitude Juniperus trees and their antimicrobial activities. Plant Biosyst 150:131-140.

Gunatilaka AAL (2006) Natural products from plant-associated microorganisms: distribution, structural diversity, bioactivity, and implications of their occurrence. J Nat Prod 69:509-526.

Hartwell JL, Johnson JM, Fitzgerald DB, Belkin M (1953) Podophyllotoxin from Juniperus species; Savinin. J Am Chem Soc 75:235-236.

Hoffman M, Gunatilaka M, Ong J, Shimabukuro M, Arnold AE (2008). Molecular analysis reveals a distinctive fungal endophyte community associated with foliage of montane oaks in Southeastern Arizona. J Arizona-Nevada Acad Sci 40:91-100.

Huang W-Y, Cai Y-Z, Xing J, Corke H, Sun M (2007) A potential antioxidant resource: endophytic fungi from medicinal plants. Econ Bot 61:14.

Jia M, Chen L, Xin HL, Zheng CJ, Rahman K, Han T, Qin LP (2016) A friendly relationship between endophytic fungi and medicinal plants: A systematic review. Front Microbiol 7:906.

Kharwar RN, Verma VC, Strobel G, Ezra D (2008) The endophytic fungal complex of Catharanthus roseus (L.) G. Don. Curr Sci 95:228-233.

Knapp DG, Pintye A, Kovács GM (2012) The dark side is not fastidious - Dark septate endophytic fungi of native and invasive plants of semiarid sandy areas. PLoS One 7(2):e32570.

Kumar S, Hyde K (2004) Biodiversity and tissue-recurrence of endophytic fungi in Tripterygium wilfordii. Fungal Divers 17:69-90.

Kusari S, Hertweck C, Spiteller M (2012) Chemical ecology of endophytic fungi: origins of secondary metabolites. Chem Biol 19:792-798.

Kusari S, Lamshöft M, Spiteller M (2009) Aspergillus fumigatus Fresenius, an endophytic fungus from Juniperus communis L. Horstmann as a novel source of the anticancer pro-drug deoxypodophyllotoxin. J Appl Microbiol 107:1019-1030.

Liu M, Quinn RJ (2019) Fragment-based screening with natural products for novel anti-parasitic disease drug discovery. Expert Opin Drug Discov 14:1283-1295.

Oksanen J, Blanchet FG, Friendly M, Kindt R, Legendre P, Minchin P (2018) Vegan: Community Ecology Package.
R Package Version. 2.4-6; 2018.

Petrini, O. (1986). Taxonomy of endophytic fungi of aerial plant tissues. In: Microbiology of the phyllosphere. In Fokkema NJ, van den Heuvel J, Eds., Cambridge University Press, Cambridge, UK, 175-187

Rana KL, Kour D, Kaur T, Devi R, Negi C, Yadav AN, Yadav N, Singh K, Saxena AN (2020) Endophytic fungi from medicinal plants: biodiversity and biotechnological applications. In Kumar A, Radhakrishnan EK, Eds., Microbial Endophytes, Woodhead Publishing, 273-305.

Sahoo S, Sarangi S, Kerry RG (2017) Bioprospecting of endophytes for agricultural and environmental sustainability. In Patra J, Vishnuprasad CN, Das G, Eds., Microbial Biotechnology, Singapore, Springer Singapore, 429-458.

Sanchez-Azofeifa A, Oki Y, Fernandes GW, Ball RA, Gamon J (2012) Relationships between endophyte diversity and leaf optical properties. Trees 26:291-299.

Selvakumar V, Panneerselvam A (2018) Bioactive compounds from endophytic fungi. In Gehlot P, Singh J. eds., Fungi and Their Role in Sustainable Development: Current Perspectives, Singapore, Springer Singapore, pp. 699-717.

Sim CSF, Cheow YL, Ng SL, Ting ASY (2018) Discovering metal-tolerant endophytic fungi from the phytoremediator plant Phragmites. Water Air Soil Pollut 229:68.

Sim CSF, Cheow YL, Ng SL, Ting ASY (2020) Can metaltolerant endophytic biocontrol agents promote plantgrowth under metal stress? Acta Biol Szeged 63(2):169179.

Strobel G, Daisy B (2003) Bioprospecting for microbial endophytes and their natural products. Microbiol Mol Biol Rev 67:491-502.

Strobel GA (2003) Endophytes as sources of bioactive products. Microbes Infect 5:535-544.

Sun X, Guo LD (2012) Endophytic fungal diversity: Review of traditional and molecular techniques. Mycology 3:1-12.

Suryanarayanand TS, Kumaresan V (2000) Endophytic fungi of some halophytes from an estuarine mangrove forest. Mycol Res 104:1465-1467.

Tan RX, Zou WX (2001) Endophytes: A rich source of functional metabolites. Nat Prod Rep 18:448-459.

Team RC (2019) R: A language and environment for statistical computing. R Foundation for Statistical Computing, Vienna, Austria. https://www.R-project.org/.

Turbat A, Rakk D, Vigneshwari A, Kocsubé S, Thu H, Szepesi Á, Bakacsy L, Škrbić B, Jigjiddorj E-A, Vágvölgyi C, Szekeres A (2020) Characterization of the plant growthpromoting activities of endophytic fungi isolated from Sophora flavescens. Microorganisms 8:683.

U'Ren JM, Lutzoni F, Miadlikowska J, Arnold AE (2010) Community analysis reveals close affinities between endophytic and endolichenic fungi in mosses and lichens. Microb Ecol 60:340-353.

Vigneshwari A, Rakk D, Németh A, Kocsubé S, Kiss N, Csu- 
por D, Papp T, Škrbić B, Vágvölgyi C, Szekeres A (2019) Host metabolite producing endophytic fungi isolated from Hypericum perforatum. PLoS One 14:e0217060.

White TJ, Bruns T, Lee S, Taylor J (1990) Amplification and direct sequencing of fungal ribosomal RNA genes for phylogenetics. In Innis MA, Gelfand DH, Shinsky JJ, White TJ, Eds., PCR protocols: A Guide to Methods and Applications. Academic Press, San Diego, 315-322. Wilson D (1995) Endophyte - the evolution of a term, and clarification of its use and definition. Oikos 73:274-276. Yo HS, Ting ASY (2017) In vitro endophyte-host plant interaction study to hypothetically describe endophyte survival and antifungal activities in planta. Acta Biol Szeged 61(1):1-11. 